\title{
Implementation of Moral \& Character Education In the Development of Student Social Life Skill in Higher Education
}

\author{
Herlina $^{a}$, Ria Herdhiana ${ }^{b}$, Mochammad Noviadi Nugroho ${ }^{c}$ \\ ${ }^{a}$ STIE Kridatama, Terusan Borobudur Street, No. 1-4, Bandung City, West Java, Indonesia \\ ${ }^{\text {b}}$ Langlang Buana University, Karapitan Street No. 116, Bandung City, West Java, Indonesia \\ ${ }^{\mathrm{c} S y a r i f ~ H i d a y a t u l l a h ~ S t a t e ~ I s l a m i c ~ U n i v e r s i t y ~ o f ~ J a k a r t a, ~ I r . ~ H . ~ J u a n d a ~ S t r e e t ~ N o . ~ 95, ~ C i p u t a t, ~ T a n g e r a n g ~ S e l a t a n, ~ I n d o n e s i a ~}$ \\ Corresponding e-mail: riaherdiana14@gmail.com
}

\begin{abstract}
Multidimensional crisis is a symptom of moral decline (character), this not only happen to adults among adults, but also has happened to the students and the students, the young shoots of hope of the nation. Parents, educators and those working in the field of religion and social behavior of many who complained against social irregularities majority of students who behave naughty, stubborn, drunkenness, brawls student and student, party drugs and other social aberrations. It is recognized that the development of the character of the nation are faced with a variety of very complex problems. The researcher will use qualitative methods, to examine the condition of the natural object, in which the researcher is a key instrument, conducted the data collection techniques combined, the data analysis is inductive, and qualitative research results further emphasize the significance of the generalization. Development of character education at the Department of Social Science Education, UIN Syarif Hidayatullah Jakarta. Character-based education can be integrated in every lecture subject, loading values into substance in all courses and teaching-learning activities that facilitate the practice of values in each learning activity inside and outside the classroom for all courses. Learning activities in each step / stage of learning at each stage facilitate learners gain targeted knowledge and skills and develop character. Assessment techniques are chosen so that overall they measure the achievement of learners in competence and character. Obstacles encountered in the implementation of Character Education on Social Life Skill Development Student Education Department of Social Studies, among others: not all lecturers understand about character education, not all lecturers apply in planning, implementation, until the evaluation of learning character.
\end{abstract}

Keywords: Moral \& Character Education; Social Life Skill; Higher Education

\section{INTRODUCTION}

The absence of a genuine willingness to make moral guidance for Indonesian education system that pays little attention to moral education. Morals and morality are closely related with the mindset, attitude to life and human behavior. Moral badness (moral hazard) are potentially lead to negative behaviors. If the bad morals of an individual, then it is very likely she will give birth to a number of irregularities that impact to social behavior could harm himself and others. Thomas Lickona - a professor of education from Cortland University - reveals that there are ten times the signs to look out for if these signs are already there, then it means that the nation was heading for the brink of collapse. The signs in question is the increasing violence among teenagers, the use of language and words are deteriorating, peer-group influence is strong in violence, increased self-destructive behavior, such as drug use, alcohol and promiscuity, the blurring of good moral guidelines and worse, declining work ethic, the lack of respect for parents and lecturers, lack of a sense of individual responsibility and citizens, dishonesty, and a sense of mutual suspicion and hatred among others. When examined, it turns out the tenth sign of the times already in Indonesia. Recent phenomenon arises violence, deviation (delinquency), criminal, and exploitation of fellow teenagers because due to adaptive conditions, social pressures, economic and cultural. The emergence of social deviation cases involve young people, both individual and collective. Ranging from mild, moderate to severe 
until, in the form of acts of infringement, deviate behavior and crime are evidence of lack of selfcontrol (faith and devotion). Therefore, formal education institutions as the official coaching youth in higher education expected to increase its role in shaping the personality of the students through the improvement in the intensity and quality of character education.

Moral and Character Education (Morale and Character Building) must be properly prepared and it must be serous in directing, shaping and developing the potential of moral, intellectual and personality. Character education has been the introduction of a new touch to the level of norms or values, and at the level of internalization and action in everyday life. Configuring the character in the context of the totality of the process of psychological and socio-cultural is grouped in: Development and implementation of character education needs to be done with reference to the grand design. Character education can be integrated in the learning in each subject. Instructional material relating to norms or values in each subject should be developed, made explicit, linked to the context of everyday life. Thus, the learning character values not only at the cognitive level, but touching on internalization, and real practice in the lives of young people in the community every day. Extra-curricular activities that have been organized school is one medium potential for character development and improving the quality of students' academic in Higher Education. Through extra-curricular activities are expected to develop skills and a sense of social responsibility, as well as the potential and achievement of students. Character education aims to improve the quality of the implementation and outcomes of education on campus leading to the formation of character and achievement of learner's noble character as a whole, integrated, and balanced. Through character education Students are expected to be able to independently increase and use knowledge, study and internalize and personalize the values of character and noble character so manifest in everyday behavior. Character education at the level of institutions leads to the formation of the school culture, the values that underlie behavior, traditions, daily habits, and symbols are practiced by all the school community, and the community around the campus.

\section{METHODS}

In this study, the researcher usedqualitative methods, to examine the condition of the natural object, in which the researcher is a key instrument, conducted the data collection techniques combined, the data analysis is inductive, and qualitative research results further emphasize the significance of the generalization.

\section{RESULTS AND DISCUSSION}

Basically, the implementation of character education in Higher Education can be done in an integrated manner in every activity. Any activity of learners in Higher Education can be used as a medium to instill character, develop relationships, and facilitate learners to behave according to prevailing values. There are at least two main channels in conducting integrated character education in Higher Education, namely: through learning activities, extracurricular activities. Integrated character education in learning is the recognition of values, the facilitation of awareness of the importance of values, and the internalization of values into the behavior of everyday learners through the learning process, both in and out of the classroom on all subjects. In the curriculum structure of IPS Education, basically each subject should contain materials related to the character. Through the learning process of planning, implementation, and assessment phases. The focus of character education is that students can understand, feel, live, and practice the values of virtue. Three components of good character (components of good character) are: knowledge of moral (moral knowing), Strengthening emotions / moral feelings (moral feeling), moral action (moral action). Character development is divided into four pillars, namely teaching and learning activities in the classroom, daily activities in the form of cultural development of educational unit; co-curricular or extra-curricular activities, as well as daily activities at home and in the community. The development of the character of learners in universities through the strengthening of content and process standards, as well as the competence of educators for the group of Personality Development (MPK) and CommunityBased Lecture (MBB); research and development of character education; guidance of educational personnel educational institutions; development and strengthening of professional character building information network is done systemically by all related directorates. Character education in teaching and learning activities in the classroom was carried out using an integrated approach in all subjects. Development of basic framework and curriculum tools; learning innovation and character building; standardization of tools and assessment processes; framework and standardization of instructional media were conducted synergistically. Integrated character education in learning is the recognition of 
values, the facilitation of awareness of the importance of values, and the internalization of values into the behavior of everyday learners through the learning process, both in and out of the classroom on all subjects. The integration of character education in subjects in universities leads to the internalization of values in everyday behavior through the learning process of the planning, implementation, and assessment phases. Character building through learning is done through recognition of values, building awareness of values, and assisting in the internalization of values or characters at this learning stage are as follows:

a. Lecturers arrive on time (example values implanted: discipline)

b. The lecturers kindly greet the students when entering the classroom (examples of values imparted: polite, caring)

c. Pray before opening lessons (example of imprinted values: religious)

d. Checking student attendance (example of embedded value: discipline)

e. Pray for students who are absent due to illness or other obstacles (example values inculcated: religious, caring)

f. Ensure that every student arrives on time (eg embedded values: discipline)

g. Reprimand a late student politely (examples of embedded values: discipline, polite, caring)

h. Linking the material / competence Learning Outcomes, to be studied with character, referring to the syllabus, SAP/RPS, and teaching materials, conveying the items of characters to be developed other than those related to $\mathrm{KI} / \mathrm{KD}$

Based on the Regulation of KKNI (Indonesian Qualification Framework), core learning activities are divided into Competencies. The following features of the learning process at exploration, elaboration, and potential confirmation stages can help students internalize the values derived from the Standards Process.

1. Involving learners looking for broad and deep information about the topic / theme of the material learned by applying the natural principles of takambang so lecturers and learning from various sources (examples of values embedded: independent, logical thinking, creative, cooperation)

2. Using a variety of learning approaches, learning media, and other learning resources (eg embedded values: creative, hard work)

3. Facilitating the interaction between students and students and lecturers, the environment, and other learning resources (examples of values invested: cooperation, mutual respect, environmental care)

4. Involving learners actively in every learning activity (eg. embedded values: self-confidence, self-reliance)

5. Facilitating learners to conduct experiments in laboratories, studios, or the field (eg embedded values: self-reliance, cooperation, hard work)

6. Facilitating learners through assignments, discussions, and others to come up with new ideas both verbally and in writing (eg embedded values: creative, confident, critical, respectful, polite)

7. Give opportunity to think, analyze, solve problems, and act without fear (examples of values invested: creative, confident, critical)

8. Facilitate learners in cooperative and collaborative learning (eg embedded values: cooperation, mutual respect, responsibility)

9. Facilitating learners to compete in a healthy way to improve learning achievement (eg embedded values: honest, disciplined, hard work, rewarding)

10. Facilitating learners to make exploratory reports both oral and written, individually or in groups (examples of values invested: honest, responsible, confident, respectful, independent, cooperative)

11. Facilitate learners to present the work of individuals and groups (examples of values invested: confidence, mutual respect, independence, cooperation)

12. Facilitating learners to exhibit, tournaments, festivals, and products produced (examples of values invested: confidence, mutual respect, independence, cooperation)

13. Facilitating learners to engage in activities that foster the pride and confidence of learners (example values embedded: confidence, mutual respect, independence, cooperation)

14. Provide positive feedback and reinforcement in the form of oral, written, gestures, or prizes to the success of learners (examples of values invested: mutual respect, confidence, polite, critical, logical)

15. Provide confirmation of the results of exploration and elaboration of learners through various sources (examples of embedded values: confident, logical, critical)

16. Facilitate learners to reflect on the learning experience they have made (example of the value invested: understand the advantages and disadvantages of self) 
17. Facilitate learners to further acquire knowledge, skills, and attitudes. Closing activity, together with learners and / or themselves make a summary / summary of the lesson (eg embedded values: independent, co-operative, critical, logical)

The purpose of enforcement activities and the discipline of academic and social life of the Campus in Student Handbook and Ethics UIN Syarif Hidayatullah Jakarta is to provide signs to the campus in:

a. Understanding the rationale of the importance of in-action character education in the practice of Campus life to shape the morality and personality of the students through the creation of climate and culture;

b. Understanding the reference values and norms and aspects that need to be developed in preparing the rules and discipline of the campus for students, the academic and social life of the campus for the head of the campus, teachers and other education personnel, and campus relationships

c. Preparing the discipline and discipline of academic and social life of the Campus in accordance with the values and norms of religion, local culture and social values, and the values that support the realization of effective learning system on campus;

d. Implementing the discipline and discipline of academic and social life of the Campus appropriately by organizing all the potential resources available to civilize noble character and noble character, monitor and evaluate on an ongoing basis, and utilize the results for classroom upgrading and student learning graduation.

e. Some activities that can be implemented by the campus in order to uphold the manners and discipline of campus academic and social life, Implement the campus order and culture, Implementing the prevailing norms and societal, growing respect and respect for campus residents

f. Among the values of characters that can be fostered through the above activities are disciplined, courteous, honest, and aware of the rights and duties of others, social and environmental concerns.

Learners as an integral part in the learning process that becomes the subject of the learner must be understood in depth by the educator to support and realize the function and purpose of national education, that is developing the ability and forming the character and civilization of dignified nation in order to educate the nation's life, to be a faithful, healthy, knowledgeable, capable, creative, independent, and being a democratic and responsible citizen. Thus, the characteristics of learners that need to be understood by educators in the context of efforts to achieve the needs of education today (education needs achievement) is the development of cognitive, affective, physical-motor, moral, intelligence, creativity, independence, personality, social, and religion.

\section{CONCLUSION}

Development of character education at the Department of Social Science Education, UIN Syarif Hidayatullah Jakarta. Character-based education can be integrated in every lecture subject, loading values into substance in all courses and teaching-learning activities that facilitate the practice of values in each learning activity inside and outside the classroom for all courses. Learning activities from the preliminary stage of activities, from the planning stage, implementation, to the evaluation of learning in all subjects, are selected and implemented so that learners practice the values of the targeted characters. Learning activities, in addition to making learners master the targeted competence (material), is also designed and done to make learners recognize, care, and internalize the values and do it in their daily life. Adaptation of learning objectives do not only develop cognitive, affective and psychomotor abilities, but also character. The learning method is altered (if required) so that the method chosen besides facilitating learners achieves targeted knowledge and skills, as well as character development. Learning activities in each step of learning at each stage facilitates learners gain targeted knowledge and skills and develop character. Assessment techniques are chosen so that overall they measure the achievement of learners in competence and character. Obstacles encountered in the implementation of Character Education on Social Life Skill Development Student Education Department of Social Studies, among others: not all lecturers understand about character education, not all lecturers apply it in planning, implementing, and evaluating learning character.

Application, meaning, and reasoning on students' values, attitudes, behavior and character impact student life. 


\section{REFFERENCE}

Anderson, L. W., \& Krathwohl, D. R. (2001). A Taxonomy for learning, teaching, and assesing. a revision of Bloom's taxonomy of education objectives. New York: Addison Wesley Longman.

Association, N. E. Preparing 21st Century Students for a Global Society: An Educator's Guide to the "Four Cs".

Asfari Rifai, et. Al. (1999). Materi Pokok Pengembangan Kurikulum dan Bahan Belajar I. Jakarta, Universitas Terbuka, Cet. 3, H.

Bappenas. (2014). Buku Pegangan Perencanaan dan Pembangunan Daerah 2014

Beers, S. Z. (2012). 21st Century Skills: Preparing Students for THEIR Future.

Borba, Michele. (2008). Building moral intelligence: The seven main virtues for a child to be moral high. Jakarta: Gramedia Pustaka Utama.

Center, P. P. (2010). 21st Century Skills for Students and Teachers. Honolulu:: Kamehameha Schools, Research \& Evaluation Division.

Dessler, G., et. al. (2004). Human Resource Management (2nd Edition). Pearson: Australia

Drake, K. (1998). Firms, Knowledge and Competitiveness. The OECD Observer, 211, pp. 24-26

Directorate of SMP Development. (2010). Character Education Guide. (Depdiknas: Jakarta).

Doni Koesoema A. (2007). Character education: The strategy of educating children in the global age. Jakarta: Grasindo. Cet. I.

Depdikbud. (1990). Indonesia Dictionary. Jakarta: Balai Pustaka.

Depdiknas. (2006). Development of Life Skills Education Model Puskur Balitbang Depdiknas. www.puskur.net

Edy Supriyadi. (2009). Development of Character Education in Junior High School (Paper as a material for developing character education guidance of Directorate of MoNE Junior High School Development).

Freire, Paulo.(1984). Pendidikan Sebagai Praktek Pembebasan, Penerjemah:Alois A. Nugroho. Jakarta: PT Gramedia.

Gibson, Lynn Kelting. (2013). Analysis of 100 Years of Curriculum Designs. International Journal of Instruction, 6 (1).

Handler, Beth (2010). Teacher as Curriculum Leader: A Consideration of the Appropriateness of that Role Assignment to Classroom-Based Practitioners. International Journal of Teacher Leadership 3 (3)

Ismanto, Bambang. (2014). Membangun Kurikulum Pendidikan Dalam Kemartabatan Bangsa Indonesia. Seminar Nasional. Pendidikan Untuk Perubahan Masyarakat Bermartabat, Dies Natalis Universitas Negeri Yogyakarta, Sabtu, 27 September 2014
Kang, M., Kim, M., Kim, B., \& You, H. (n.d.). Developing an Instrumen to Measure 21st Century Skills for Elementary Student.

Krathwohl, D. R. (2002). A Revision of Bloom's Taxonomy: An Overview. THEORY INTO PRACTICE , pp. 212-232.

Keliat, M., et. al. Pemetaan Pekerja Terampil Indonesia dan Liberalisasi Jasa ASEAN. Laporan Penelitian ASEAN Study Center UI bekerja sama dengan Kementerian Luar Negeri Republik Indonesia.

Kemendiknas. (2010). Character Education at Junior High School. Jakarta: Kemendiknas

Kevin Ryan \& Karen E. Bohlin. (1999). Building character in schools: Practical ways to bring moral instruction to life. San Francisco: Jossey Bass.

Kirschenbaum Howard. (1995). 100 ways to enhance values and morality in schools nd youth settings. Massachusetts: Allys \& Bacon.

Lester, James P and Stewart, J. (2000). Public Policy: An Evolutionary Approach. The University of California: Wadsworth Thomson Learning.

Mc. Kenly. Steve, Positive Youth Develovment \& Life skill Develovment, Iowa State University, http: //www.extention.iastate

NCREL \& Metiri Group. (2003). enGange 21st century skills: literacy in the digi $\neg$ tal age.

Peraturan Menteri Pendidikan Dan Kebudayaan Republik Indonesia, Nomor 73 Tahun 2013 Tentang Penerapan Kerangka Kualifikasi Nasional Indonesia. Bidang Pendidikan Tinggi

Peraturan Menteri Pendidikan Dan Kebudayaan, Republik Indonesia, Nomor : 49 Tahun 2014 Tentang Standar Nasional Pendidikan Tinggi

Peraturan Pemerintah Republik Indonesia Nomor 4 Tahun 2014 Tentang Penyelenggaraan Pendidikan Tinggi Dan Pengelolaan Perguruan Tinggi

Primrose, K. \& Alexander, C. R. (2013) Curriculum development and implementation: factors contributing towards curriculum development in Zimbabwe higher education system. European Social Sciences Research Journal, 1(1), pp. 5565.

Porter, Michael. (1990). Competitive Advantage on Nations. New York: Free Press

Ryan Kevin and Bohlin Karen. (1999). Building character in schools. San Francisco: John Willey \& Sons.

Rotherham, A. J., \& Willingham, D. (2009). 21st Century Skills: the challenges ahead. Educational Leadership, 67 (1), pp. $16-21$.

Syaifudin, Azwar. (1993). Psychological scale-up. Yogyakarta: Andi Offset

Skills, P. f. ( ). Learning for the 21st century skills. Tucson,: Partnership for 21 st Century Skills.

Sudjana, Nana. (1989). Pembinaan dan Pengembangan Kurikulum di Sekolah Kejuruan. Bandung: PT SInar Baru. 